\title{
Invasive and Noninvasive Mechanical Ventilation For Acute Exacerbations Of Chronic Obstructive Pulmonary Disease: A Comparative Study.
}

\author{
Abd-Hay I. Abd-Hay; Ahmed S. Alsaily* and Essam A. El-Moselhy** \\ Departments of Chest, Anesthesia* and Community Medicine** \\ Faculty of Medicine, Al-Azhar University
}

\begin{abstract}
Introduction: Acute exacerbation of chronic obstructive pulmonary disease (COPD) is a frequent cause of hospitalization and intensive care unit admission. Respiratory failure from airflow obstruction is a direct consequence of acute airway narrowing. Aim of the study: It was to compare the efficacy of noninvasive mechanical ventilation (NIMV) against conventional mechanical ventilation (CMV) in patients with acute exacerbation of COPD. Patients and methods: Forty patients with acute exacerbation of COPD were recruited in the present study. A comparative, hospital based study design was used. All the cases were examined; clinically and laboratory. The patients were divided into two groups each include 20 patients. Group A received NIMV in the form of continuous positive airway pressure (CPAP) and group B with CMV. Results: There were statistically significant decreases in respiratory rate, heart rate and diastolic blood pressure after 6 hours of CPAP in comparison to baseline parameters in group A. While, there were statistically significant increases in $\mathrm{PaO} 2$ and $\mathrm{SaO} 2$ after 6 hours of CPAP in comparison to baseline parameters. In group B there were statistically significant decreases in respiratory rate, heart rate, systolic blood pressure and diastolic blood pressure after 6 hours of $\mathrm{CMV}$ in comparison to baseline parameters. While, there were statistically significant increases in $\mathrm{pH}, \mathrm{PaO} 2$, and $\mathrm{SaO} 2$ and a statistically significant decrease in $\mathrm{PaCO} 2$ after 6 hours of $\mathrm{CMV}$ in comparison to baseline parameters. Further, comparison of respiratory rate and hemodynamic parameters in both groups showed statistically significant decreases in respiratory rate, heart rate, systolic blood pressure and diastolic blood pressure in group A in comparison to group B. Finally, failure rate was $35.0 \%$ in group A (NIMV) compared to $5.0 \%$ in group B (CMV) with statistically significant difference. Conclusions and recommendations: Noninvasive mechanical ventilation is a safe and effective means of improving gas exchange in patients with acute exacerbations of CPPD. If patient not respond to NIMV, CMV should be used. Further studies are needed to evaluate the appropriate selection of patients and to find the best level and schedule of ventilation.
\end{abstract}




\section{Introduction}

Acute exacerbation of chronic obstructive pulmonary diseases (COPD) is a frequent cause of hospitalization and intensive care unit (ICU) admission. Respiratory failure from airflow obstruction is a direct consequence of acute airway narrowing and critical increases in airway resistance. These lead to two important mechanical changes; first, the increased pressures required for airflow may overload respiratory muscles, producing a "ventilatory pump failure" and second, the narrowed airways create regions of lung that cannot properly empty and return to their normal resting volume. This sometimes is called air trapping and produces elevated end-expiratory pressures (intrinsic positive end-expiratory pressure [PEEPi] or auto-PEEP) (MacIntyre \& Huang, 2008 and Aboussouan, 2010).

The primary objectives of mechanical ventilator support in patients with COPD exacerbations are to decrease morbidity and mortality and to relieve symptoms. Ventilator support includes both noninvasive and invasive (conventional) mechanical ventilation by oro-tracheal tube or tracheostomy. Patients with hypercapnic forms of acute respiratory failure (ARF) are most likely to benefit from mechanical ventilation. Their respiratory muscles become unable to generate adequate alveolar ventilation despite large pressure swings because of the presence of severe abnormalities in respiratory mechanics (intrinsic positive end-expiratory pressure (PEEP) and high inspiratory resistances) (Brochard et al., 1990).

Noninvasive mechanical ventilation (NIMV) has been studied in several randomized controlled trials in acute respiratory failure. It improves respiratory acidosis (increases $\mathrm{pH}$, and decreases $\mathrm{PaCO} 2$ ), decreases respiratory rate, severity of breathlessness and length of hospital stay. However, NIMV is not appropriate for all patients as those in respiratory arrest, cardiovascular instability (hypotension, arrhythmias and myocardial infarction), uncooperative patients, high aspiration risk, viscous or copious secretions, craniofacial trauma and burns (Esteban et al., 1995 and Antonelli et al., 1998).

The expected improvement in arterial blood gas tensions with NIMV varies and is affected by the underlying pathology and severity of respiratory decompensation. Most trials which describe a positive response to treatment, including randomized controlled trials, have noted an early improvement in $\mathrm{PaO}_{2}$, $\mathrm{pH}$, and $\mathrm{PaCo}_{2}$. This is usually evident at 1 hour and certainly at 4-6 hours. Lack of progress towards correction of disturbance of these parameters has been associated with failure of NIMV. A degree of stability should be reached by 4-6 hours (Kramer et al., 1995 and GOLD, 2009).

Invasive mechanical ventilation should be considered in patients whose $\mathrm{pH}, \mathrm{PaCO}_{2}$, and respiratory rate have deteriorated or failed to improve within four hours of initiation of NIMV. Noninvasive ventilation is less likely to be successful in such patients, or in those with severe acidosis such as an initial $\mathrm{pH}$ <7.26. Moreover, patients who remain acidotic 48 hours after starting treatment with NIMV tend to have a poor prognosis. Such patients have a higher mortality if NIMV is continued than if mechanical ventilation is initiated, and the latter treatment should therefore be considered (Plant, 2006 and Tremblay \& Slutsky, 2006). 


\section{Aim of the work}

Noninvasive mechanical ventilation is beneficial for patients with acute exacerbation of COPD when added to medical treatment. However, its role as an alternative to conventional mechanical ventilation (CMV) remains controversial. Our aim was to compare the efficacy of NIMV against CMV in patients with acute exacerbation of COPD.

\section{Patients and methods}

This study included 40 male patients with acute exacerbation of COPD attending the Emergency Room, Chest Clinic or admitted in Chest Inpatients Department, Bab-Alsharrayea, Al-Azhar University Hospital and need to be admitted to intensive care unit. Ages of the patients ranged from 52 to 64 years. The patients were diagnosed and studied through:

1- Thorough history taking from the patient or relative.

2- Full clinical examination.

3- Plain chest $x$-ray.

4- Previous or recent spirometric tests if possible (FVC, FEVI and FEVI/FVC).

5- Routine laboratory investigations including complete blood picture, fasting and post prandial serum glucose level SGOT, SGPT, blood urea, and creatinine. Serum biochemistry (albumin, potassium and sodium);

6- Haemodynamic variables (blood pressure, heart rate, ECG)

7- Blood gas analysis.

Patients were divided into two groups each one includes 20 patients:
Group A: NIMV was given with an aircushioned face via a mechanical ventilator (puritan-Bennett 318 CPAP-system apparatus) with initial setting of $10 \mathrm{~cm}$ $\mathrm{H}_{2} \mathrm{O}$ continuous positive airway pressure (CPAP) in semi-sitting position added to standard medical treatment including inhaled $\beta_{2}$ agonists, anticholinergic agents, intravenous corticosteroids, xanthines and, when appropriate, antibiotics, furosemide, antiarrhythmics or vasoactive agents. Oxygen was added to achieve a $\mathrm{SaO}_{2}$ of $>90.0 \%$. The patients' ECG, $\mathrm{SaO}_{2}$, blood pressure, and respiratory rate were continuously monitored. NIMV was delivered almost continuously in the first 6 hours with short intervals of spontaneous breathing with oxygen supplementation to allow the patients to drink, expectorate and, in some cases, eat.

Treatment failure criteria: Respiratory arrest, respiratory pauses with loss of consciousness or gasping, respiratory rate above 35 breaths per minute and above the value on admission, psychomotor agitation making nursing care impossible and requiring sedation, heart rate below 50 beats/minute with loss of alertness, and hemodynamic instability with systolic arterial blood pressure below $70 \mathrm{~mm} \mathrm{Hg}$. Patients were mechanically ventilated in the assist-control mode.

Group B: All patients were intubated orally and assist-control ventilation was applied. Standard settings for assistcontrol ventilation were used: Tidal volume, approximately 8 to $10 \mathrm{~mL} / \mathrm{kg}$; respiratory rate 12 to 16 breaths/minute; and an inspired oxygen fraction $\left(\mathrm{FIO}_{2}\right)$ as required obtaining a $\mathrm{SaO}_{2}$ of about $95.0 \%$.

Exclusion criteria: Patients with chest wall deformity, patients with restrictive lung disease, patients with any cardiac diseases, patients with liver 
diseases, and patients with renal failure, respiratory arrest, respiratory pauses with loss of consciousness or gasping, psychomotor agitation making nursing care impossible and requiring sedation.

\section{Statistical analysis}

All statistical calculations were done using computer programs Microsoft Excel Version 7 (Microsoft Corporation, NY, USA) and SPSS (Statistical Package for the Social Science; SPSS Inc., Chicago, USA) statistical program. Data were statistically described in terms of range, mean (M), standard deviation (SD), frequencies (number of cases) and relative frequencies (percentages) when appropriate. The t-student test and 2-tailed Fisher exact (FE) were used as tests of significance. The data obtained were compared in tables of t-values to determine the critical values for the samples, and its statistical significance with the $\mathrm{P}$ value. Also, $\mathrm{FE}$ was used to test statistical significant relation of qualitative data (percentages). The significance level for $\mathrm{t}$ and $\mathrm{FE}$ was accepted if the P-value $<0.05$.

\section{Results}

There were no statistically significant differences between the studied groups A (NIMV) and B (CMV) as regard to age, respiratory rate, hemodynamic parameters (heart rate, and systolic and diastolic blood pressure) (table 1), $\mathrm{pH}$ and pulmonary gases exchange ( $\mathrm{PaCO} 2, \mathrm{PaO} 2$, $\mathrm{SaO} 2$ and $\mathrm{HCO} 3$ ) (table 2) at admission.

As regard respiratory and hemodynamic parameters of group A (NIMV) before and after 6 hours of noninvasive (CPAP) ventilation (table 3), there were statistically significant decreases in respiratory rate $(32.7 \pm 8.9$ vs. $26.2 \pm 5.3$ breathes/minute, $\mathrm{P}=0.004)$, heart rate $\quad(105.0 \pm 12.0 \quad$ vs. $91.0 \pm 11.0$ beats/minute, $\mathrm{P}=0.0002$ ) and diastolic blood pressure $(94.7 \pm 7.8$ vs. $84.2 \pm 5.2 \mathrm{~mm}$ $\mathrm{Hg}, \mathrm{P}=0.000$ ) after 6 hours of CPAP in comparison to baseline parameters. On the other hand, there was insignificant decreases in systolic blood pressure $(133.0 \pm 18.0$ vs. $130.2 \pm 12.0$ breathes/ minute, $\mathrm{P}=0.2$ ) in group A after 6 hours of CPAP in comparison to baseline parameters.

There were significant decreases in respiratory rate $(31.9 \pm 9.3$ vs. $22.3 \pm 5.3$ breathes/minute), heart rate $(109.0 \pm 14.0$ vs. $82.0 \pm 13.0$ beats/minute), systolic blood pressure $(137.0 \pm 23.0$ vs. $124.0 \pm 13.0 \mathrm{~mm}$ $\mathrm{Hg}$ ) and diastolic blood pressure $(96.0 \pm 14.0$ vs. $87.0 \pm 12.0 \mathrm{~mm} \mathrm{Hg})$ in group B after 6 hours of CMV in comparison to baseline parameters (table 4).

Comparison between the studied groups A and B as regard respiratory and hemodynamic parameters after 6 hours of ventilation (table 5) showed significant decreases in respiratory rate $(26.2 \pm 5.3$ vs. $22.3 \pm 5.3$ breathes/minute, $\mathrm{P}=0.01$ ), heart rate $\quad(91.0 \pm 11.0 \quad$ vs. $82.0 \pm 13.0$ beats/minute, $\mathrm{P}=0.01)$, systolic blood pressure $(133.0 \pm 12.0$ vs. $124.0 \pm 13.0 \mathrm{~mm}$ $\mathrm{Hg}, \mathrm{P}=0.01)$ and diastolic blood pressure (84.2 \pm 5.2 vs. $81.3 \pm 2.3 \mathrm{~mm} \mathrm{Hg}, \mathrm{P}=0.01$ ).

As regard blood gases and acid base parameters of group A before and after 6 hours of noninvasive (CPAP) ventilation (table 6 and figure 1), there were significant increases in $\mathrm{PaO} 2$ (53.6 \pm 5.8 vs. $67.2 \pm 5.6 \mathrm{~mm} \mathrm{Hg}, \mathrm{P}=0.000)$ $\begin{array}{llll}\text { and } & \mathrm{SaO} 2 & \% & (82.7 \pm 6.87 \\ \text { vs. }\end{array}$ $91.9 \pm 8.89 \%, \quad \mathrm{P}=0.0003)$. On the other hand, there were insignificant increase in 
$\mathrm{pH}(7.32 \pm 0.05$ vs. $7.34 \pm 0.03, \mathrm{P}=0.06)$ and $\mathrm{HCO} 3 \quad(22.7 \pm 4.6$ vs. $23.2 \pm 4.3 \mathrm{mEq} / \mathrm{L}$, $\mathrm{P}=0.36$. Lastly, there was insignificant decrease in $\mathrm{PaCO} 2 \quad(61.7 \pm 12.4$ vs. 58.2 $\pm 9.4 \mathrm{~mm} \mathrm{Hg}, \mathrm{P}=0.15)$.

In group $\mathrm{B}$ there were significant increases in $\mathrm{pH}(7.31 \pm 0.04$ vs. $7.36 \pm 0.04$, $\mathrm{P}=0.000), \mathrm{PaO} 2$ (54.2 \pm 4.9 vs. $85.6 \pm 12.6$ $\mathrm{mm} \mathrm{Hg}, \mathrm{P}=0.000)$, and $\mathrm{SaO} \%$ (81.9 47.9 vs. $95.5 \pm 8.6 \%, \mathrm{P}=0.000)$ and a significant decrease in $\mathrm{PaCO} 2 \quad(63.2 \pm 14.7$ vs. $51.2 \pm 8.4 \mathrm{~mm} \mathrm{Hg}, \mathrm{P}=0.001$ ) after 6 hours of $\mathrm{CMV}$ in comparison to baseline parameters (table 7 and figure 2 ).

At the same time, there were statistically significant increases in $\mathrm{pH}$
(7.34 \pm 0.03 vs. $7.36 \pm 0.04, \mathrm{P}=0.03), \mathrm{PaCO} 2$ (58.2 \pm 9.4 vs. $51.2 \pm 8.4 \mathrm{~mm} \mathrm{Hg}, \mathrm{P}=0.008)$ and $\mathrm{PaO} 2(67.2 \pm 5.6$ vs. $85.6 \pm 5.6 \mathrm{~mm} \mathrm{Hg}$, $\mathrm{P}=0.000$ ) in groups $\mathrm{A}$ and $\mathrm{B}$, respectively (table 8 and figure 3 ). On the other hand, there were statistically insignificant increase in $\mathrm{SaO} 2 \% \quad(91.9 \pm 8.9$ vs. $95.5 \pm 8.6 \%, \mathrm{P}=0.10)$ and $\mathrm{HCO} 3(23.2 \pm 4.3$ vs. $23.7 \pm 6.2 \mathrm{mEq} / \mathrm{L}, \mathrm{P}=0.38$ ) in groups $\mathrm{A}$ and $\mathrm{B}$, respectively.

Finally, table (9 and figure 4) showed that the number of intubated patients (failure rate) was $7(35.0 \%)$ in group A (NIMV) compared to 1 patient $(5.0 \%)$ in group B (CMV) with statistically significant difference $(\mathrm{P}=0.04)$.

Table (1): Demographic and clinical baseline of respiratory and hemodynamic parameters of the studied groups A (noninvasive mechanical ventilation [NIMV]) and B (conventional mechanical ventilation [CMV]).

\begin{tabular}{|l|c|c|c|c|}
\hline \multicolumn{1}{|c|}{ Variables } & $\begin{array}{c}\text { Group A } \\
\text { NIMV } \\
\text { M } \pm \text { SD } \\
(\mathrm{n}=20)\end{array}$ & $\begin{array}{c}\text { Group B } \\
\text { CMV } \\
\text { M } \pm \text { SD } \\
(\mathrm{n}=20)\end{array}$ & $\begin{array}{c}\mathrm{t}- \\
\text { value }\end{array}$ & $\begin{array}{c}\text { P- } \\
\text { value }\end{array}$ \\
\hline Age (years) & $54.0 \pm 9.8$ & $55 \pm 10.7$ & -0.308 & 0.379 \\
\hline Respiratory rate (breathes/min.) & $32.7 \pm 8.9$ & $31.9 \pm 9.3$ & 0.278 & 0.608 \\
\hline Heart rate (beats/min.) & $105 . \pm 12.0$ & $109.0 \pm 14.0$ & -0.97 & 0.169 \\
\hline Systolic blood pressure $\mathrm{mm} \mathrm{Hg}$ & $133.0 \pm 18.0$ & $137.0 \pm 23.0$ & -0.612 & 0.271 \\
\hline Diastolic blood pressure $\mathrm{mm} \mathrm{Hg}$ & $94.7 \pm 7.8$ & $96.2 \pm 6.9$ & -0.644 & 0.260 \\
\hline
\end{tabular}

Table (2): Baseline blood gases and acid base parameters in both studied groups $\mathrm{A}$ (noninvasive mechanical ventilation [NIMV]) and B (conventional mechanical ventilation [CMV]).

\begin{tabular}{|l|c|c|c|c|}
\hline Variables & $\begin{array}{c}\text { Group A } \\
\text { NIMV } \\
\text { M } \pm \text { SD } \\
(\mathrm{n}=20)\end{array}$ & $\begin{array}{c}\text { Group B } \\
\text { CMV } \\
\mathrm{M} \pm \text { SD } \\
(\mathrm{n}=20)\end{array}$ & $\begin{array}{c}\text { t- } \\
\text { value }\end{array}$ & $\begin{array}{c}\text { P- } \\
\text { value }\end{array}$ \\
\hline $\mathrm{pH}$ & $7.32 \pm 0.05$ & $7.31 \pm 0.04$ & 0.698 & 0.754 \\
\hline $\mathrm{PaCO} 2 \mathrm{~mm} \mathrm{Hg}$ & $61.7 \pm 12.4$ & $63.2 \pm 14.7$ & -0.349 & 0.364 \\
\hline $\mathrm{PaO} 2 \mathrm{~mm} \mathrm{Hg}$ & $53.6 \pm 5.8$ & $54.2 \pm 4.9$ & -0.353 & 0.362 \\
\hline $\mathrm{SaO} 2 \%$ & $82.7 \pm 6.87$ & $81.9 \pm 7.89$ & 0.342 & 0.630 \\
\hline $\mathrm{HCO} 3 \mathrm{mEq} / \mathrm{L}$ & $22.7 \pm 4.6$ & $21.12 \pm 6.3$ & 0.906 & 0.811 \\
\hline
\end{tabular}


Table (3): Respiratory and hemodynamic parameters of group A (noninvasive mechanical ventilation) before and after 6 hours of noninvasive (CPAP) ventilation.

\begin{tabular}{|c|c|c|c|c|}
\hline \multirow{2}{*}{ Variables } & \multicolumn{2}{|c|}{ Group A $(n=20)$} & \multirow{2}{*}{$\begin{array}{c}\mathrm{t}- \\
\text { value }\end{array}$} & \multirow{2}{*}{$\begin{array}{c}\mathrm{P}- \\
\text { value }\end{array}$} \\
\hline & $\begin{array}{c}\text { Baseline } \\
\mathrm{M} \pm \mathrm{SD}\end{array}$ & $\begin{array}{c}\text { After } 6 \text { hours } \\
M \pm S D\end{array}$ & & \\
\hline Respiratory rate (breathes $/ \mathrm{m}$ ) & $32.7 \pm 8.9$ & $26.2 \pm 5.3$ & -2.806 & 0.004 \\
\hline Heart rate (beats/min.) & $105.0 \pm 12.0$ & $91.0 \pm 11.0$ & -3.846 & 0.0002 \\
\hline Systolic blood pressure $\mathrm{mm} \mathrm{Hg}$ & $133.0 \pm 18.0$ & $130.0 \pm 12.0$ & -0.62 & 0.270 \\
\hline Diastolic blood pressure $\mathrm{mm} \mathrm{Hg}$ & $94.7 \pm 7.8$ & $84.2 \pm 5.2$ & -5.009 & 0.000001 \\
\hline
\end{tabular}

Table (4): Respiratory and hemodynamic parameters of group B (conventional mechanical ventilation) before and after 6 hours of invasive mechanical ventilation.

\begin{tabular}{|c|c|c|c|c|}
\hline \multirow{2}{*}{ Variables } & \multicolumn{2}{|c|}{ Group B $(n=20)$} & \multirow{2}{*}{$\begin{array}{c}\mathrm{t}- \\
\text { value }\end{array}$} & \multirow{2}{*}{$\begin{array}{c}\mathrm{P}- \\
\text { value }\end{array}$} \\
\hline & $\begin{array}{l}\text { Baseline } \\
\mathrm{M} \pm \mathrm{SD}\end{array}$ & $\begin{array}{c}\text { After } 6 \text { hours } \\
M \pm S D\end{array}$ & & \\
\hline Respiratory rate (breathes $/ \mathrm{m}$ ) & $31.9 \pm 9.3$ & $22.3 \pm 5.3$ & -4.011 & 0.00019 \\
\hline Hear t rate (beats/min.) & $109.0 \pm 14.0$ & $82.0 \pm 13.0$ & -6.32 & 0.00 \\
\hline Systolic blood pressure $\mathrm{mm} \mathrm{Hg}$ & $137.0 \pm 23.0$ & $124.0 \pm 13.0$ & -2.201 & 0.018 \\
\hline Diastolic blood pressure $\mathrm{mm} \mathrm{Hg}$ & $96.0 \pm 14.0$ & $87.0 \pm 12.0$ & 2.183 & 0.0179 \\
\hline
\end{tabular}

Table (5): Comparison between the studied groups A (noninvasive mechanical ventilation) and $B$ (conventional mechanical ventilation) as regard respiratory and hemodynamic parameters after 6 hours of ventilation.

\begin{tabular}{|l|c|c|c|c|}
\hline \multicolumn{1}{|c|}{ Variables } & $\begin{array}{c}\text { Group A } \\
\text { after 6 hours } \\
\mathrm{M} \pm \mathrm{SD} \\
(\mathrm{n}=20)\end{array}$ & $\begin{array}{c}\text { Group B } \\
\text { after 6 hours } \\
\mathrm{M} \pm \mathrm{SD} \\
(\mathrm{n}=20)\end{array}$ & $\begin{array}{c}\mathrm{t}- \\
\text { value }\end{array}$ & $\begin{array}{c}\text { P- } \\
\text { value }\end{array}$ \\
\hline Respiratory rate (breathes/m) & $26.2 \pm 5.3$ & $22.3 \pm 5.3$ & -2.327 & 0.013 \\
\hline Hear t rate (beats/min.) & $91.0 \pm 11.0$ & $82.0 \pm 13.0$ & -2.364 & 0.012 \\
\hline Systolic blood pressure $\mathrm{mm} \mathrm{Hg}$ & $133.0 \pm 12.0$ & $124.0 \pm 13.0$ & -2.275 & 0.014 \\
\hline Diastolic blood pressure $\mathrm{mm} \mathrm{Hg}$ & $84.2 \pm 5.2$ & $81.3 \pm 2.3$ & -2.281 & 0.0157 \\
\hline
\end{tabular}


Table (6): Blood gases and acid base parameters of group A (noninvasive mechanical ventilation) before and after 6 hours of noninvasive (CPAP) ventilation.

\begin{tabular}{|c|c|c|c|c|}
\hline \multirow{2}{*}{ Variables } & \multicolumn{2}{|c|}{ Group A $(n=20)$} & \multirow{2}{*}{$\begin{array}{c}\mathrm{t}- \\
\text { value }\end{array}$} & \multirow{2}{*}{$\begin{array}{c}\mathrm{P}- \\
\text { value }\end{array}$} \\
\hline & $\begin{array}{c}\text { Baseline } \\
\mathrm{M} \pm \mathrm{SD}\end{array}$ & $\begin{array}{c}\text { After } 6 \text { hours } \\
M \pm S D\end{array}$ & & \\
\hline $\mathrm{pH}$ & $7.32 \pm 0.05$ & $7.34 \pm 0.03$ & -1.534 & 0.06 \\
\hline $\mathrm{PaCO} 2 \mathrm{~mm} \mathrm{Hg}$ & $61.7 \pm 12.4$ & $58.2 \pm 9.4$ & -1.006 & 0.158 \\
\hline $\mathrm{PaO} 2 \mathrm{~mm} \mathrm{Hg}$ & $53.6 \pm 5.8$ & $67.2 \pm 5.6$ & -7.544 & 0.000 \\
\hline $\mathrm{SaO} 2 \%$ & $82.7 \pm 6.87$ & $91.9 \pm 8.89$ & -3.662 & 0.0003 \\
\hline $\mathrm{HCO} 3 \mathrm{mEq} / \mathrm{L}$ & $22.7 \pm 4.6$ & $23.2 \pm 4.3$ & -0.355 & 0.362 \\
\hline
\end{tabular}

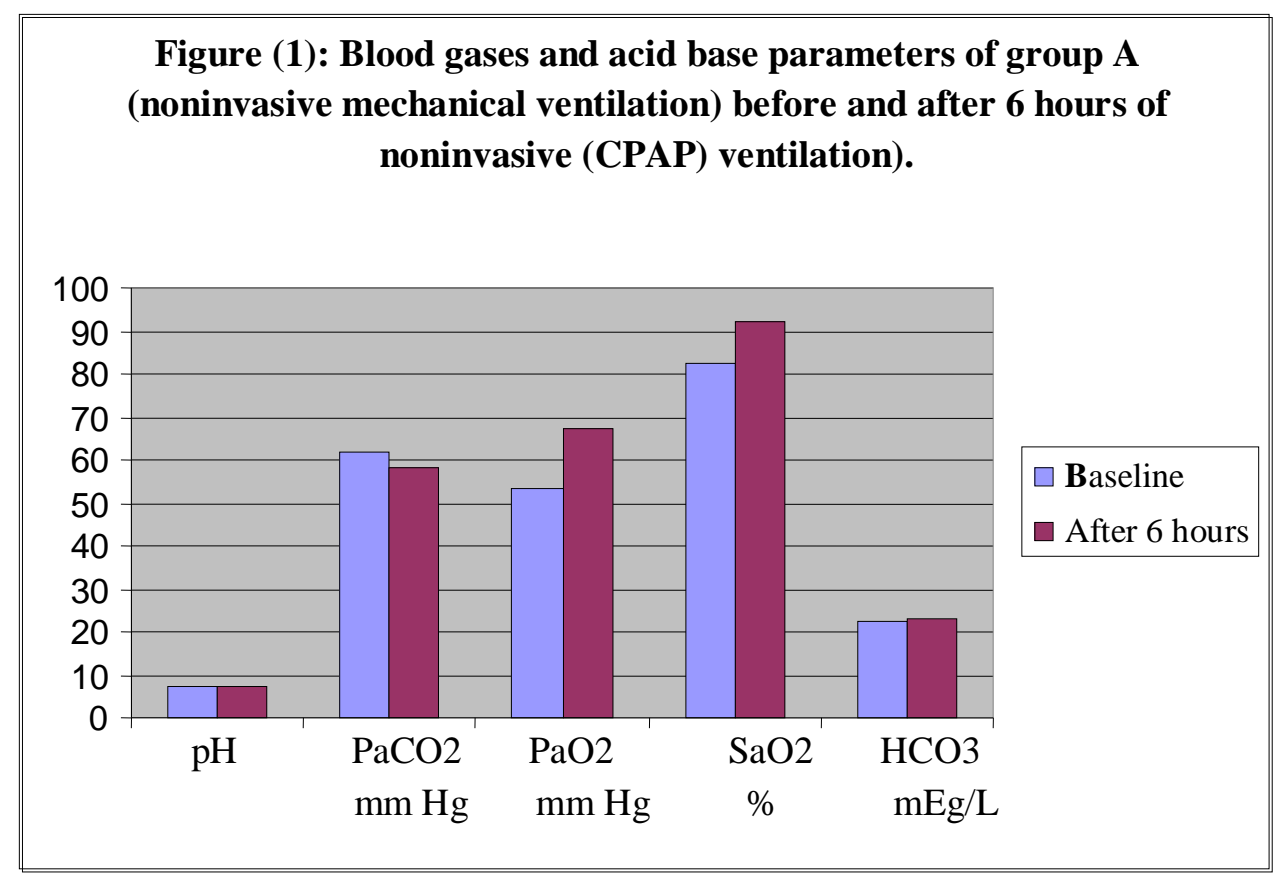

Table (7): Blood gases and acid base parameters of group B (conventional mechanical ventilation) before and after 6 hours of invasive mechanical ventilation.

\begin{tabular}{|l|c|c|c|c|}
\hline \multirow{2}{*}{ Variables } & \multicolumn{2}{|c|}{ Group B $(\mathrm{n}=20)$} & \multirow{2}{t}{$\begin{array}{c}\text { - } \\
\text { value }\end{array}$} & $\begin{array}{c}\text { P- } \\
\text { Value }\end{array}$ \\
\cline { 2 - 3 } & $\begin{array}{c}\text { Baseline } \\
\mathrm{M} \pm \mathrm{SD}\end{array}$ & $\begin{array}{c}\text { After 6 hours } \\
\mathrm{M} \pm \mathrm{SD}\end{array}$ & & \\
\hline $\mathrm{pH}$ & $7.31 \pm 0.04$ & $7.36 \pm 0.04$ & -3.953 & 0.0001 \\
\hline $\mathrm{PaCO} 2 \mathrm{~mm} \mathrm{Hg}$ & $63.2 \pm 14.7$ & $51.2 \pm 8.4$ & -3.17 & 0.001 \\
\hline $\mathrm{PaO} 2 \mathrm{~mm} \mathrm{Hg}$ & $54.2 \pm 4.9$ & $85.6 \pm 12.6$ & -10.381 & 0.000 \\
\hline $\mathrm{SaO} 2 \%$ & $81.9 \pm 7.9$ & $95.5 \pm 8.6$ & -5.211 & 0.000 \\
\hline $\mathrm{HCO} 3 \mathrm{mEq} / \mathrm{L}$ & $21.9 \pm 6.3$ & $23.7 \pm 6.2$ & -0.911 & 0.184 \\
\hline
\end{tabular}




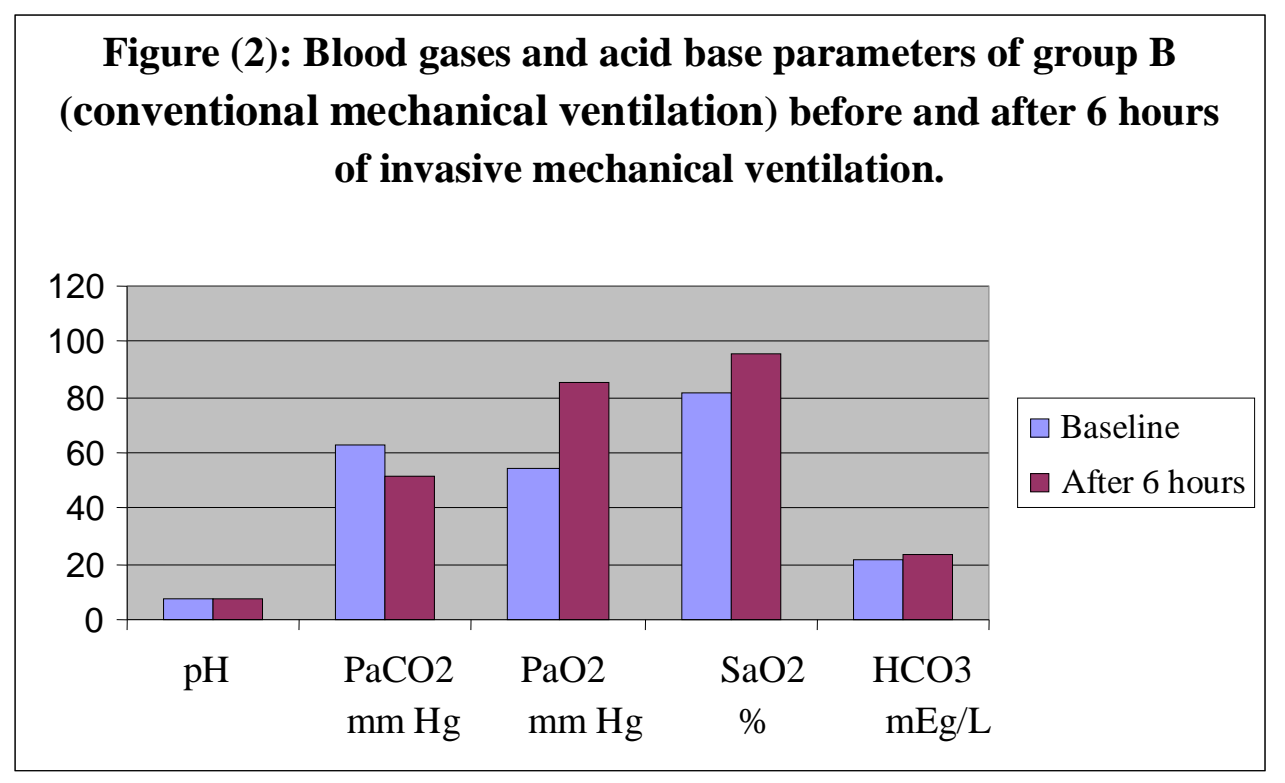

Table (8): Comparison between the studied groups A (noninvasive mechanical ventilation) and $B$ (conventional mechanical ventilation) as regard blood gases and acid base parameters after 6 hours of ventilation.

\begin{tabular}{|l|c|c|c|c|}
\hline Variables & $\begin{array}{c}\text { Group A } \\
\text { after 6 hours } \\
\mathrm{M} \pm \text { SD } \\
(\mathrm{n}=20)\end{array}$ & $\begin{array}{c}\text { Group B } \\
\text { after 6 hours } \\
\mathrm{M} \pm \mathrm{SD} \\
(\mathrm{n}=20)\end{array}$ & $\begin{array}{c}\mathrm{t}- \\
\text { value }\end{array}$ & $\begin{array}{c}\mathrm{P}- \\
\text { value }\end{array}$ \\
\hline $\mathrm{pH}$ & $7.34 \pm 0.03$ & $7.36 \pm 0.04$ & -1.789 & 0.039 \\
\hline $\mathrm{PaCO} 2 \mathrm{~mm} \mathrm{Hg}$ & $58.2 \pm 9.4$ & $51.2 \pm 8.4$ & 2.483 & 0.008 \\
\hline $\mathrm{PaO} 2 \mathrm{~mm} \mathrm{Hg}$ & $67.2 \pm 5.6$ & $85.6 \pm 5.6$ & -10.39 & 0.000 \\
\hline $\mathrm{SaO} 2 \%$ & $91.9 \pm 8.9$ & $95.5 \pm 8.6$ & -1.301 & 0.1004 \\
\hline $\mathrm{HCO} 3 \mathrm{mEq} / \mathrm{L}$ & $23.2 \pm 4.3$ & $23.7 \pm 6.2$ & -0.296 & 0.3841 \\
\hline
\end{tabular}

Figure (3): Comparison between the studied groups A (noninvasive mechanical ventilation) and $B$ (conventional mechanical ventilation) as regard blood gases and acid base parameters after 6 hours of ventilation.

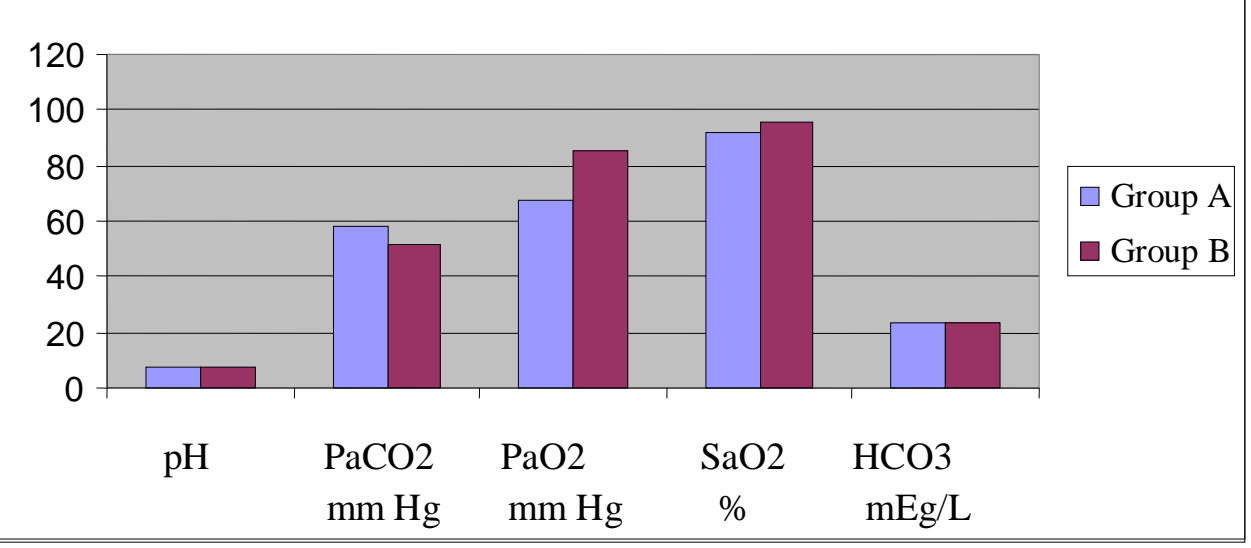


Table (9): The percentage of treatment failure in both groups A (noninvasive mechanical ventilation) and $B$ (conventional mechanical ventilation).

\begin{tabular}{|l|c|c|c|c|}
\hline \multirow{2}{*}{} & \multicolumn{2}{|c|}{ Group A } & \multicolumn{2}{c|}{ Group B } \\
\cline { 2 - 5 } & No.=20 & $\%$ & No.=20 & $\%$ \\
\hline Success & 13 & 65.0 & 19 & 95.0 \\
\hline Failure & 7 & 35.0 & 1 & 5.0 \\
\hline $\begin{array}{l}\text { Fisher Exact } \\
\text { P- value }\end{array}$ & \multicolumn{3}{|c|}{0.0435} \\
\hline
\end{tabular}

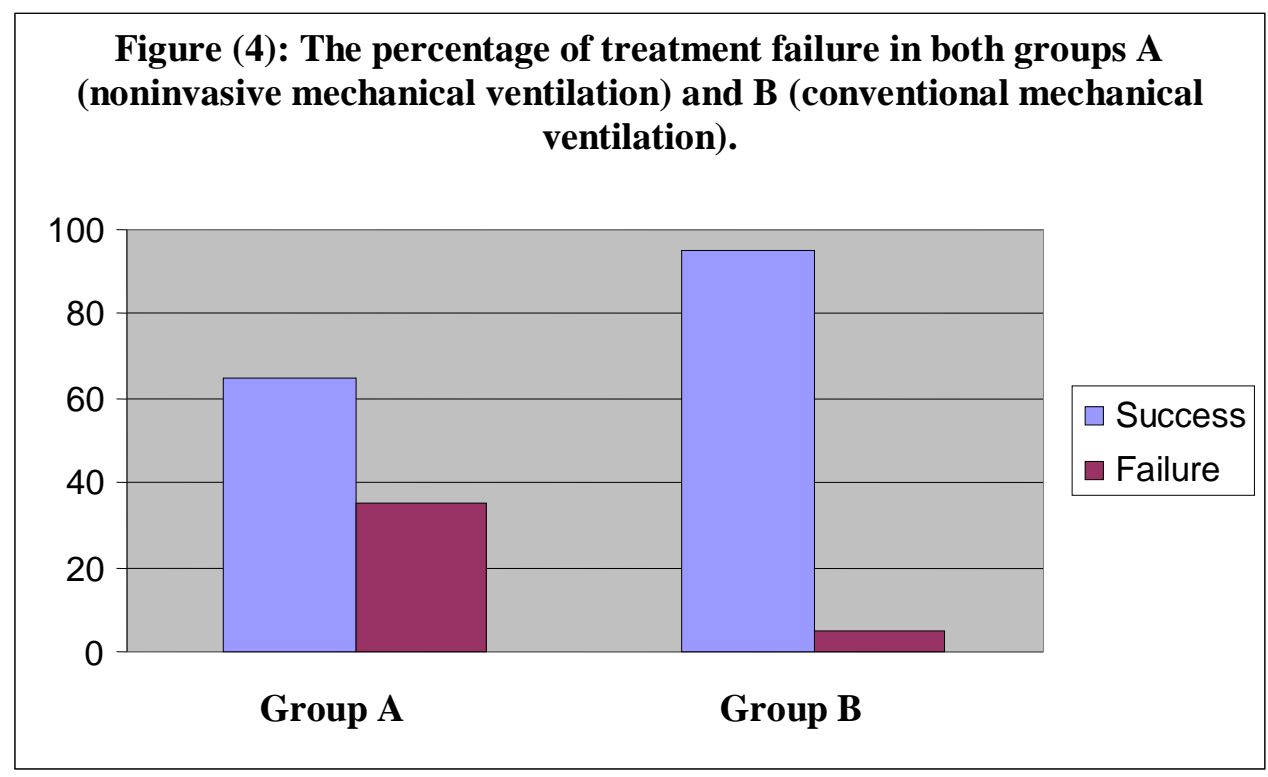

\section{Discussion}

Periodic exacerbations of symptoms are the major cause of morbidity, mortality and health care costs in patients with COPD (Yetkin and Gunen, 2008). Conventional treatment for patients with chronic obstructive pulmonary disease aims to ensure adequate continuous oxygenation and to treat the cause of the exacerbation usually achieved through treatment with bronchodilators, corticosteroids, antibiotics, and controlled oxygen. Noninvasive ventilation may be a good alternative approach for these patients (Ambrosino et al., 1995).
The advantages of NIMV over invasive ventilation are that it preserves normal physiologic functions such as coughing, swallowing, feeding, and speech and avoids the risks of tracheal and laryngeal injury and respiratory tract infections (Aboussouan, 2010).

The addition of NIMV to standard care in patients with an acute exacerbation of COPD decreased the rate of endotracheal intubation, length of hospital stay and in-hospital mortality rate (Diaze et al., 1997 and Keenan et al., 2003). CPAP is employed in patients with acute respiratory failure to correct hypoxemia. It permits higher inspired oxygen content than other methods of oxygen 
supplementation, increases mean airway pressure, and will improve ventilation to collapsed areas of the lung. The recruitment of underventilated lung is similar to the use of PEEP in the intubated mechanically ventilated patient (BTS Guideline, 2002).

This study compared the efficacy of NIMV against CMV on pulmonary gas exchange, blood pressure, respiratory rate and heart rate in patients with acute exacerbation of COPD. Our results agreed with Honrubia et al. (2005) who compared noninvasive vs. conventional mechanical ventilation in acute respiratory failure and concluded that NIMV reduces the need for intubation and therapeutic intervention in patients with ARF from different causes. Further. Meduri et al. (1996) concluded that mechanical ventilation via face mask offers an effective, comfortable, and dignified method of supporting patients with endstage disease and acute respiratory failure.

Brochard et al. (1995) studied the effect of face mask pressure support ventilation (PSV) or standard medical therapy alone on 85 patients with hypercapnic respiratory failure due to COPD and concluded that in selected patients with acute exacerbations of chronic obstructive pulmonary disease, noninvasive ventilation can reduce the need for endotracheal intubation, the length of the hospital stay, and the in-hospital mortality rate. At the same time, Çelikel (1998) compared noninvasive positive pressure ventilation (NIPV) with standard medical therapy in hypercapnic acute respiratory failure and found that patients with NIPV, $\mathrm{PaO}_{2}(\mathrm{p}<0.001)$, and respiratory rate $(\mathrm{p}$ $<0.001$ ) improved significantly compared with baseline. Gottfried et al. (1991) found that the use of nasal CPAP (5 to 9.3 $\mathrm{cm}$ H2O) was associated with improvement in $\mathrm{PaO} 2$ and only few patients' required invasive ventilation. kramer et al. (1995) have found more rapid improvements in blood gas levels in the noninvasive positive pressure ventilation (NPPV) group compared with the group of conventional treatment, despite having similar baseline vital signs. The results of this study were also in agreement with Goldberg et al. (1995) and Lim (1996) who reported that $\mathrm{PaO} 2$ has increased, and $\mathrm{PaCO} 2$ and respiratory rate have decreased in the CPAP group.

As regard $\mathrm{pH}$, our results disagree with Plant et al. (2000) who found rapid improvements in arterial $\mathrm{pH}$ in the NPPV group compared to the conventional medical group. This might be due to prolonged duration during which NPPV has been applied giving enough time to kidneys to compensate for changes in $\mathrm{pH}$ and resting the fatigued muscles helping $\mathrm{CO} 2$ wash.

With respect to $\mathrm{HCO} 3$ our results disagree with Çelikel et al. (1998) who found that $\mathrm{HCO} 3$ was significantly increased while heart rate and blood pressure didn't change significantly in any time.

As regard the intubation rate, Connors and colleagues (1996) in a study of 1016 patients admitted to hospital with an acute exacerbation of COPD complicated by hypercapnia, reported intubation rate of $35.0 \%$, a percentage similar to our result. Also, Guérin et al. (1998) reported a prospective observational study of 320 patients requiring mechanical ventilation, conducted over a 2-year period in a single ICU at a university teaching hospital. Of the 98 patients who initially received NIV, $39.0 \%$ required ETI, a percentage similar to the results of our study.

Brochard et al. (1995) showed that 11 of 43 patients $(26.0 \%)$ in the noninvasive-ventilation group were 
intubated and concluded that the use of noninvasive ventilation significantly reduced the need for endotracheal intubation. Also, Carlucci et al. (2001) reported that the addition of NPPV to standard care in patients with an acute exacerbation of COPD decreased the rate of endotracheal intubation (risk reduction, 28.0\%). Honrubia et al. (2005) showed that in patients with an acute exacerbation of COPD on NPPV, $40 \%$ were intubated, vs. $100.0 \%$ in the conventional mechanical ventilation group, and these results were comparable with our results. The results of this study disagreed with Kramer et al. (1995) who found a significant reduction in the need for intubation in patients treated with non-invasive ventilation $(9.0 \%)$ over those receiving standard medical treatment $(66.0 \%)$. Conti et al. (2002) conducted a randomized prospective study comparing noninvasive positive pressure ventilation with conventional mechanical ventilation via endotracheal intubation in a group of patients with chronic obstructive pulmonary disease who failed standard medical treatment in the emergency ward and found that in the NPPV group 11 (48.0\%) patients avoided intubation. Confalonieri et al. (1996) evaluated short- and long-term (1 year) outcome of early administration of NPPV in 24 patients with ARF due to exacerbated COPD (group I) in comparison with 24 matched historical-control patients treated conventionally (group II) and found that Only $2(8.0 \%)$ patients of group I needed endotracheal intubation. Masip et al. (2000) found that endotracheal intubation was required in one $(5.0 \%)$ of 19 patients assigned NPPV and in six (33.0\%) of 18 assigned conventional oxygen therapy $(\mathrm{p}=0.037)$.

As regard comparison between both groups our results disagreed with
Conti et al. (2002) who cleared that both NPPV and conventional ventilation significantly improved gas exchanges. The two groups had similar length of ICU stay, number of days on mechanical ventilation, overall complications, ICU mortality, and hospital mortality. In the NPPV group 11 (48.0\%) patients avoided intubation, survived, and had a shorter duration of ICU stay than intubated patients. This might be due to prolonged duration during which NPPV has been applied. Antonelli et al. (1998) reported that in patients with ARF, NIV was as effective as CMV in improving gas exchange and was associated with fewer serious complications and shorter stays in ICU. Vitacca et al. (1996) concluded that for patients suffering from COPD who have undergone ARF, avoiding ETI by early treatment with NIMV is associated with better survival in comparison to patients bound to invasive MV. Pneumonia as a cause of ARF may worsen the prognosis in both groups of patients.

\section{Conclusions and recommendations}

Non-invasive mechanical ventilation is a safe and effective means of improving gas exchange in patients with acute exacerbations of chronic obstructive pulmonary disease. If patient not respond to noninvasive mechanical ventilation, conventional mechanical ventilation should be used. The advantages of this approach could include avoiding the complications associated with endotracheal intubation, preserving airway defense mechanisms, speech and swallowing. Further studies are needed on large numbers of patients to evaluate the appropriate selection of patients and to find the best level and schedule of ventilation. 


\section{References}

Aboussouan L (2010): Noninvasive positive pressure ventilation: Increasing use in acute care. Cleveland Clin J Med, 77(5): 307-16.

Ambrosino N, Foglio K, Rubini F, Clini E, Nava $S$ and Vitacca $M$ (1995): Non-invasive mechanical ventilation in acute respiratory failure due to chronic obstructive pulmonary disease: correlates for success. Thorax, 50: 755-7.

Antonelli M, Conti G, Rocco M, Bufi M, De Blasi RA, Vivino G, Gasparetto $A$ and Meduri GU (1998): A comparison of noninvasive positive-pressure ventilation and conventional mechanical ventilation in patients with acute respiratory failure. N Engl J Med, 339(7): 429-35.

Brochard L, Isabey D, Piquet J, et al. (1990): Reversal of acute exacerbations of chronic obstructive lung disease by inspiratory assistance with a face mask. N Engl J Med, 323: 1523-30.

Brochard L, Mancebo J, Wysocki M, et al. (1995): Noninvasive ventilation for acute exacerbations of chronic obstructive pulmonary disease. N Engl J Med, 333: 81722.

BTS Guideline (2002): Non-invasive ventilation in acute respiratory failure. Thorax, 57: 192-211.

Carlucci A, Richard JC, Wysocki M, Lepage $E$ and Brochard $L$ (2001): Noninvasive versus conventional mechanical ventilation: An epidemiologic survey. Am J Respir Crit Care Med, 163(4): 874-80.

Çelikel T, Sungur M, Ceyhan B and Karakurt S (1998): Comparison of noninvasive positive pressure ventilation with standard medical therapy in hypercapnic acute respiratory failure. Chest, 114(6): 1636-42.

Confalonieri M, Parigi P, Scartabellati A, Aiolfi S, Scorsetti, Nava S and Gandola $\mathbf{L}$ (1996): Noninvasive mechanical ventilation improves the immediate and long-term outcome of COPD patients with acute respiratory failure. Eur Respir J, 9: 422-30.

Connors AF, Dawson NV, Thomas C, Harrell FE, Desbiens N, Fulkerson WJ, Kussin P, Bellamy P, Goldman $L$ and
Knaus WA (1996): Outcomes following acute exacerbation of severe chronic obstructive lung disease. Am J Respir Crit Care Med, 154: 95967.

Conti G, Antonelli M, Navalesi P, Rocco M, Bufi M, Spadetta G and Meduri GU (2002): Noninvasive vs. conventional mechanical ventilation in patients with chronic obstructive pulmonary disease after failure of medical treatment in the ward: a randomized trial. Intensive Care Med, 12: 1701-7.

Diaze O, Iglesia R, Ferrer M, et al. (1997): Effects of noninvasive ventilation on pulmonary gas exchange and hemodynamics during acute exacerbations of chronic obstructive pulmonary disease. Am J Respir Crit Care Med, 156: 1840-5.

Esteban A, Frutos F, Tobin MJ, Alia I, Solsona JF, Valverdu I, et al. (1995): A comparison of four methods of weaning patients from mechanical ventilation- Spanish Lung Failure Collaborative Group. N Engl J Med, 332: 345-50.

GOLD (2009): Global strategy for diagnosis, management, and prevention of COPD. Workshop Report, update 2009. Bethesda, MD: National Institutes of Health, National Heart, Lung and Blood Institute; 2005. Available from: http://www.goldcopd.com/.

Goldberg P, Reissmann H, Maltaise F, Ranieri $M$ and Gottfried SB (1995): Efficacy of noninvasive CPAP in COPD with acute respiratory failure. Eur Respir J, 8: 1894-900.

Gottfried SB (1991): The role of PEEP in mechanically ventilated COPD patient. In: Ventilator failure, Berlyn Marini JJ and Rossos C (Eds.), Springer-Verlag, 392-418.

Guérin C, Girard R, Chemorin C, De Varax $R$ and Fournier $G$ (1998): Facial mask noninvasive mechanical ventilation reduces the incidence of nosocomial pneumonia: A prospective epidemiological survey from a single ICU. Intensive Care Med, 23: 1024-32.

Honrubia T, García López FJ, Franco N, Mas M, Guevara M, Daguerre M, Alía I, Algora A and Galdos P (2005): Noninvasive vs. conventional mechanical ventilation in acute respiratory failure: A multicenter randomized controlled trial. Chest, 128(6): 3916-24. 
Keenan SP, Sinuff T, Cook DJ and Hill NS (2003): Which patients with acute exacerbation of chronic obstructive pulmonary disease benefit from noninvasive positivepressure ventilation? A systematic review of the literature. Ann Intern Med, 138(11): 86170 .

Kramer N, Meyer TJ, Meharg J, Cece RD and Hill NS (1995): Randomized, prospective trial of non-invasive positive pressure ventilation in acute respiratory failure. Am J Resp Crit Care Med, 151: 1799-806.

Lim TK (1996): Treatment of severe exacerbations of chronic obstructive pulmonary disease with mask-applied continuous positive airway pressure. Respirology, 1: 189-93.

Masip J, Betbesé AJ, Páez J, Vecilla F, Cañizares R, Padró J, Paz MA, de Otero J and Ballús J (2000): Non-invasive pressure support ventilation versus conventional oxygen therapy in acute cardiogenic pulmonary oedema: A randomised trial. Lancet, 356: 2126-32.

Meduri GU, Turner RE, Abou-Shala N, Wunderink $R$ and Tolley $E$ (1996): Noninvasive positive pressure ventilation via face mask: First-line intervention in patients with acute hypercapnic and hypoxemic respiratory failure. Chest, 109(1): 179-93.
MacIntyre N and Huang YC (2008): Acute exacerbations and respiratory failure in chronic obstructive pulmonary disease. The Proceedings of the American Thoracic Society, 5: 530-5.

Plant PK (2006): ABC of chronic obstructive pulmonary disease and ventilatory support. BMJ, 333: 138-40.

Plant PK, Owen JL and Elliott MW (2000): Early use of non-invasive ventilation for acute exacerbations of chronic obstructive pulmonary disease on general respiratory wards: A multicentre randomised controlled trial. Lancet, 355: 1931-5.

Tremblay LN and Slutsky AS (2006): Ventilator-induced lung injury: From the bench to the bedside. Intensive Care Med, 32: 24-33.

Vitacca M, Clini E, Rubini F, Nava S, Foglio $K$ and Ambrosino N (1996): Non-invasive mechanical ventilation in severe chronic obstructive lung disease and acute respiratory failure: Short- and long-term prognosis. Intensive Care Med, 22(2): 94-100.

Yetkin $O$ and Gunen $H$ (2008): Inspiratory capacity and forced expiratory volume in the first second in exacerbation of chronic obstructive pulmonary disease. Clin Respir J, 2(1): 36-40. 


\section{التففس الصناعى التاخلى و اللاتداخلى فى المرضى ذوى الاتتكاس الحاد

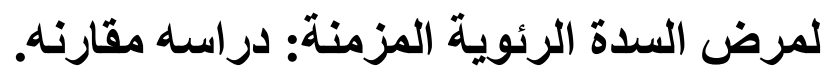

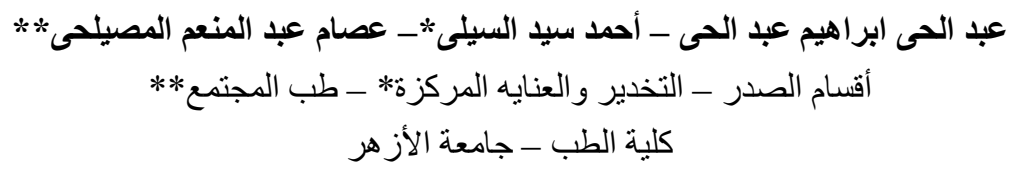

الإنتكاس الحاد لمرض السدة الرئوية المزمنة سبب منكرر من أسباب دخول المستشفيات ووحدة

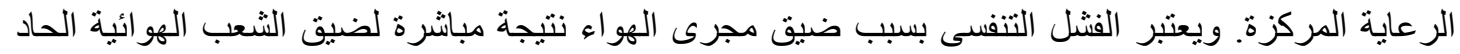

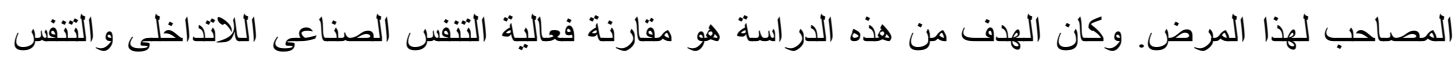
الصناعى التداخلى بو اسطة الأنبوب الحنجرى فى المرضى ذونى الإنى هذه الاتكاس الحاد لمرض السدة الرئوية المزمنة.

وقد أُجريت هذه الدر اسة على أربعين مريضاًً بالانتكاس الحاد لمرض السدة الرئوية المزمنة. وقد تم

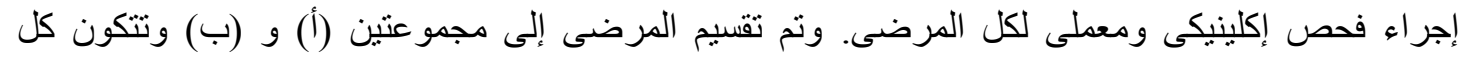

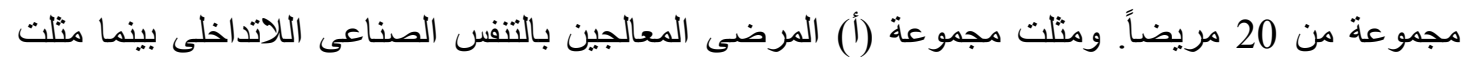
مجموعة (ب) المرضى المعالجين بالتنفس الصناعى التداخلى بو اسطة الأنبوب الحنجرى.

وقد بينت الدر اسة أن هناك انخفاض ذو دلالة مؤثرة إحصائباً فى متوسط معدل التنفس ومتوسط معدل

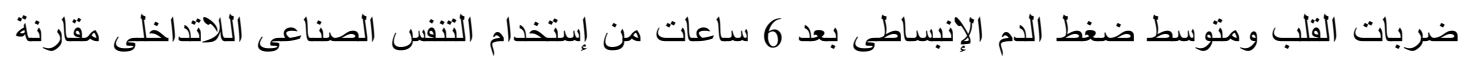

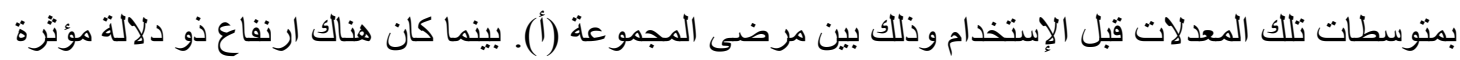

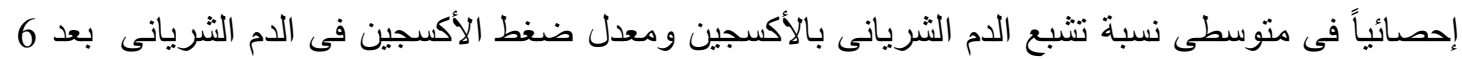

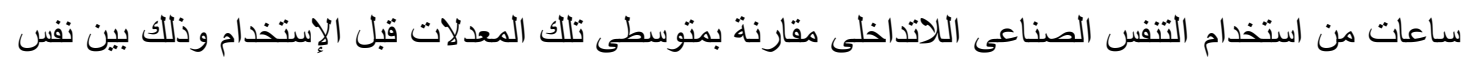

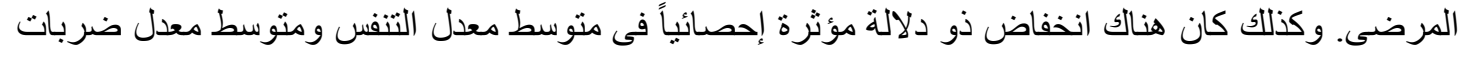

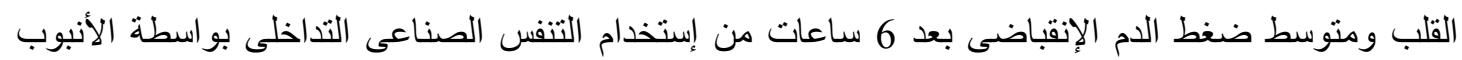

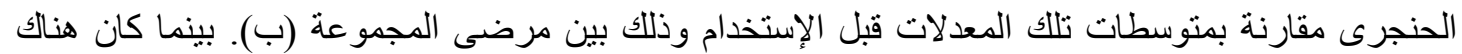

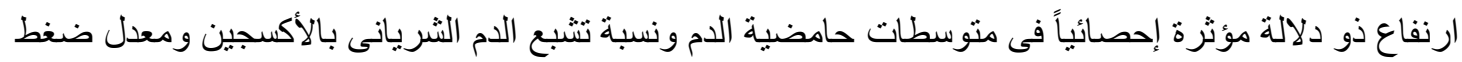

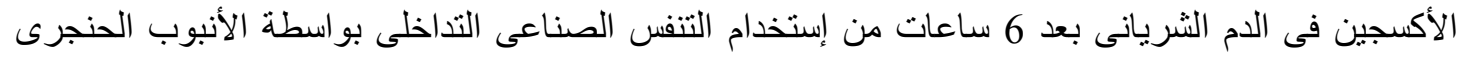

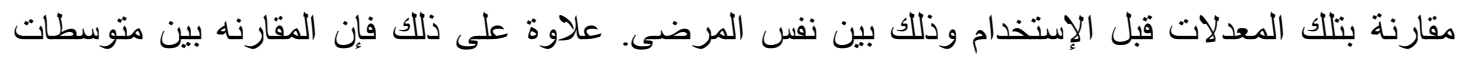

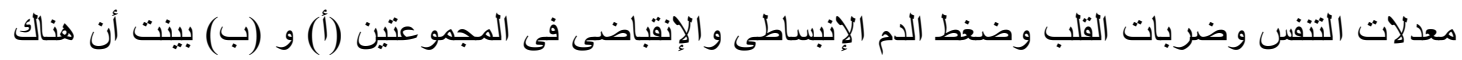

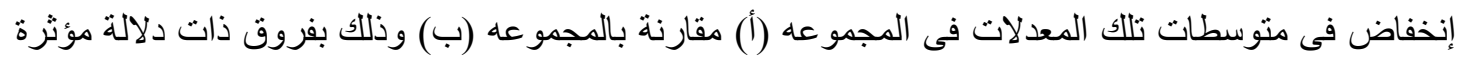

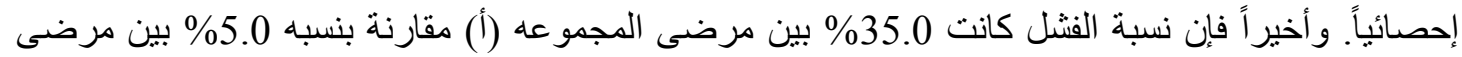
المجمو عه (ب) وذلك بفروق ذات دلالة مؤثرة إحصائياً.

وقد استخلص البحث أن التنفس الصناعى اللاتداخلى يعتبر وسيله آمنه وفعاله لتحسين تبادل الغازات

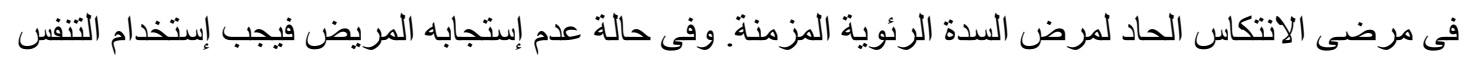

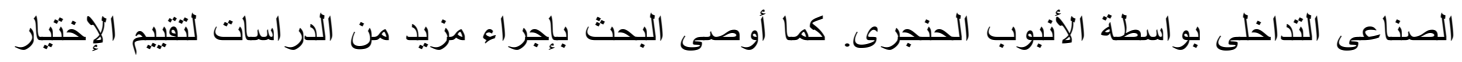

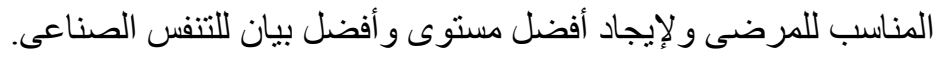

